\title{
Military expenditure in Colombia: macroeconomic and microeconomic aspects
}

\section{Yaneth Giha Tobar \\ Economist, Analyst in the Military Forces and Police \\ Division, National \\ Department of Planning, \\ Colombia.}

Héctor Riveros Reyes

Economist, Analyst in the

same Division.

Andrés Soto Velasco Politologist, Head of the

Justice and Security Unit,

National Department

of Planning.
This article analyses defence and security spending (DSS) in Colombia, on the assumption that in order to gain a better idea of the effect of such spending on economic growth and the public finances it would be desirable to analyse its internal composition, since this would make it possible to infer its impact on the production of defence and security. In order to do this, various theories on the repercussions of military expenditure are reviewed and defence and security spending in Colombia is analysed on the basis of information from the Office of the Comptroller-General of the Republic. The efficiency of spending on the armed forces and the National Police is then examined, especially as regards the relations between combat and support and attack and defence, and it is shown that the military forces need to be reorganized. In the conclusions, various ways of securing savings on the defence budget are proposed. The most important of these are connected with personnel management, as payroll expenses represent $73 \%$ of total spending. The proposals made in this respect are to modify the system of pay and allowances, increase the retirement age, reduce the number of personnel and restructure the proportions between combat forces and support and administrative personnel. 


\section{I}

\section{Introduction}

The armed conflict in Colombia has given rise to discussions about defence and security spending (DSS). Those in favour of such spending consider that DSS is vital for strengthening the Public Forces, that improving the security forces of the State increases the likelihood of consolidating a climate of peace and tranquillity in which the rights of the individual prevail, and that it has a positive influence on demand and employment. Its critics, on the other hand, argue that DSS is unproductive, that rather than improving the social environment it limits the public resources available for investing in areas with a greater social impact, and also that Colombia is making a disproportionate economic effort because of the current armed conflict.

Although these propositions are based on apparently incontrovertible assumptions, we will nevertheless try in this article to analyse the underlying postulates. We will begin by summarizing the debate on the effects of DSS on the economy. The basic premise of those who believe that DSS is unproductive is that any outlay in this field has negative effects on the economy and also displaces resources which would otherwise generate greater value added. In order to determine if the rationalization of DSS really gives a "peace dividend", however, we must first know what impact that spending has on the economy. In order for the rationalization of DSS to make economic sense, the benefits generated by the saving on DSS for different areas of security must be greater than the impact of DSS itself.

It may be gathered from the international studies made on military spending ${ }^{1}$ since the 1970 s that the results on this matter are not conclusive. It must be borne in mind, however, that the debate on the optimum level of DSS is not an abstract exercise, because in the final analysis the economic resources used are

$\square$ The authors wish to express their thanks for the assistance rendered in terms of coordination by Luis Jorge Garay and the valuable comments of Gabriel Piraquive Galeano. The views expressed in this article are of course the sole responsibility of the authors and do not necessarily reflect the views of the institution they belong to or of other government bodies. the means selected for achieving an objective through military action. It is therefore necessary to compare the repercussions in terms of security with the financial and economic consequences of the expenditure.

The analysis of the situation of Colombia is based on the widely held view that the effort made by Colombia to deal with the armed conflict is disproportionately large. To a large extent, this view may be due to the growing feeling that the country's objectives in terms of security seem increasingly far off, while the financial, economic and social resources devoted to their pursuit are ever greater. However, it is not enough merely to analyse DSS in the light of its possible impact on the State finances. In the final analysis, it is the internal composition of that spending which can enable us to infer its real effect on the production of defence and security, which is its ultimate objective. Examining this aspect will give us a sounder basis for our macroeconomic analysis.

We will therefore make a detailed examination of DSS in Colombia, on the basis of the reports of the Office of the Comptroller-General of the Republic. This information breaks down the resources into operating expenses and investment: that is to say, outlays on the pay and pensions of both the civil and military personnel in question, general expenditure, and outlays on military and police capital formation. In the specific case of Colombia, this item is called Expenditure on the Public Forces (EPF). This category covers all the expenditure on the military forces (including the functioning of the Ministry of Defence and other agencies involved in defence projects) and the expenditure on police forces and auxiliary military forces organized in the event of conflict. The aim of breaking down EPF in detail is to determine

\footnotetext{
${ }^{1}$ In this article, military spending is equated with defence and security spending (DSS) and expenditure on Public Forces (EPF). This is because since 1950 the budget of the National Police is incorporated in the budget of the Ministry of Defence and, according to the definition of military spending used by the North Atlantic Treaty Organization (NATO), which is the definition we have followed here, the police carry out activities which require resources typical of such spending.
} 
the line it has followed in Colombia, for which purpose its past behaviour is studied and its structural and conjunctural components are identified.

It is also noted that the costs in this sector can only be reduced if changes are made in personnel management and the administration of physical resources. Improving the way the Public Forces oper- ate would make it possible to increase their capacity to provide defence and security. The microeconomic analysis made of the sector provides an opportunity to explore possible options for making EPF redound in higher levels of defence and security and to determine how far it can be reduced while making it more efficient.

\section{II}

\section{Theoretical analysis of the economic impact of military spending}

Since 1973 there has been a strong ongoing controversy about the impact of military spending on economic growth. Some circles maintain that such spending is unproductive, arguing that all outlays in this field have negative effects on the economy and limit the resources available for investment in areas that provide greater social benefits. Others, however, believe that military spending favours economic growth insofar as it makes a significant contribution to increasing national production capacity.

Those who argue that there is a negative relation between military spending and the economic and social development indicators assert that although such expenditure is a necessary strategy for the capitalist system it has an adverse impact on the growth rate because it leads to lower levels of investment.

Recent studies have been investigating the macroeconomic effects of military spending in the less developed countries and have found that it adversely affects growth, the balance of payments current account, saving and investment. A significant difference has also been observed between the level of military spending of military dictatorships and that of civilian governments. The studies conclude that if the security of a nation depends on economic growth, then expenditure on its military forces only seems to be buying insecurity and underdevelopment (Smith, 1977; Deger, 1986; Nabe, 1983; Ball, 1983; Leontief and Duchin, 1983; Pivetti, 1992).

Most developing nations have considerable difficulty in balancing their fiscal resources while trying to meet the growing demands of their costly armed forces. Thus, according to some analysts, a kind of military Malthusianism has been growing up: a con- frontation between small annual increases in fiscal resources but soaring increases in defence costs. In many countries, the cost of providing the military apparatus exceeds their capacity of payment. For many reasons, a vicious circle has been forming since the 1970s: as the military bureaucracy grows, militarily useless but increasingly costly equipment is acquired, crowding out social expenditure and public investment and ultimately reducing the well-being of the population, while because of their lack of technical and economic capacity the armed forces find it difficult to provide real defence against outside threats, so that their central role shifts to internal repression and control of the friction between civil and military elements caused by the reduction in well-being, which finally leads to a further increase in military spending. This process generally takes place in the less developed countries (Scheetz, 1991).

In contrast, the authors who have been maintaining that the higher a country's military spending, the greater its economic growth, believe that such spending can be economically productive if it leads to a situation of national security and allows for the more effective exercise of property rights, thus stimulating private investment and hence growth. They also note that spending on military capital formation can have productive effects: some developing countries are still benefitting from transport and communications facilities constructed for military purposes.

It has thus been maintained that military spending is an item capable of providing food, lodging, medical services and training to a number of persons who would otherwise have to be maintained by the 
civilian sector; that -as already mentioned- it can bring forward the execution of a wide range of public works which also benefit the civilian economy, and that it can cover various special forms of scientific and technological development which would otherwise have to be carried out by the civilian sector of society (Benoit, 1973; Thompson, 1974; Frederiksen and Looney, 1982).

Finally, while it may be noted that individual studies on the effect of military spending on economic growth come to apparently contradictory conclusions, Todd Sandler and Keith Hartley conclude

\section{III}

\section{Hypothesis}

The study of military spending is of interest to a number of different disciplines because of its effects on the level of public expenditure and on economic growth. In times of peace, or at least when the survival of values and institutions does not depend on massive use of the military apparatus, the idea is that macroeconomic considerations should govern the discussion on the desirable and possible level of military spending: that is to say, such controversies are settled in the final analysis by fiscal capacity.

It is worth exploring the reasons why the analysis of such spending is of interest, however. For economists, it is of great importance because of its impact on growth and on the macroeconomic variables. For those who make public decisions, it is essential to study this spending because of its effects on the public finances and the crowding out of resources that it can cause in other areas of central government expenditure. Few analysts have focussed on the true justification for military expenditure, however: the capacity to provide defence and security.

In view of the foregoing, discussions about the proper level of military spending cannot be productive unless they take microeconomic aspects into account. Study of the composition of military spending makes it possible to infer its real impact on the production of defence and security, while at the same time giving a more concrete basis on which to carry out the macroeconomic analysis; it is also of fundamental importance for determining future trends in military spending. If this expenditure consists mainly that -whatever the samples used, the periods analysed, or the econometric methods employed- the models based on the influence of demand generally hold that military spending crowds out investment and therefore has a negative effect, whereas the studies centered on supply aspects generally find that the effects are positive or neutral. This leads them to conclude that the net impact of military spending on growth is only slightly negative, so that the reduction of military spending alone is not a desirable way of speeding up economic growth (Sandler and Hartley, 1995, especially p. 220).

of payments for the remuneration of personnel, then the possibilities of reducing it go down. The opposite is true, however, in the case of investment and operational expenditure. We thus see that the possibility of making changes in military spending is inversely proportional to the proportion of payroll costs and directly proportional to operational and investment costs.

Study of the evolution of military spending in Colombia reveals that its cycles of expansion and contraction are the result of transitory equipment acquisition programmes, while salary increases and reclassifications raise expenditure levels and make them difficult to reduce. Consequently, fiscal adjustment programmes affecting the military sector risk weakening its operational capacity: the discretionality of the expenditure may mainly affect the investment and operational items and thus give rise to an imbalance between military personnel and the material resources available to it.

Therefore, although it is extremely important to analyse the impact of military spending on the economic growth and public finances of a country, such analysis will be insufficient if it does not take account of the internal composition of the expenditure, for it is this structure which makes it possible to infer the effect that the expenditure will have on the economy and the possibilities of reducing it and making it more efficient, while at the same time evaluating the effect this will have on the provision of defence and security. 


\section{IV}

\section{Defence and security spending}

\section{Past behaviour}

A review of expenditure on the Public Forces $(\mathrm{EPF})^{2}$ in Colombia from 1926 to the present shows that on average the economy has devoted $1.8 \%$ of GDP to security, with a minimum of $0.5 \%$ in 1930 and a maximum of $3.6 \%$ in 1997 (figure 1). This evolution shows a cyclical pattern of expansion and contraction of the security budget, with however an upward trend over the period. A more detailed analysis (table 1) shows that in the late 1920 s this expenditure averaged $0.7 \%$ of GDP. This level was maintained up to 1932, the year before the border dispute with Peru broke out. This conflict brought EPF up to one of the highest levels registered by the country: around 3\%. Afterwards, over a period of four years, this expenditure was brought down to less than $1.5 \%$ of GDP. This shows that although the external conflict made necessary a big effort, this was due to transitory factors which permitted it to be rapidly reduced later (figure 1 and table 1).

In the 1940s, a somewhat remarkable situation prevailed: although the Second World War was taking place elsewhere, in Colombia the level of expenditure on the Public Forces, as a percentage of GDP, was below its historical trend level. Only towards the end of that decade and the beginning of the 1950s was there a renewed substantial increase in EPF, which rose from less than $1.1 \%$ of GDP to over $2.1 \%$. This period coincided with important domestic events, such as the period of unrest known as "La Violencia", due to conflicts between the political parties, and the 1953-1957 military dictatorship of General Gustavo Rojas Pinilla.

Nevertheless, towards the end of the 1950s the growth of EPF had dropped back to levels close to the historical average. In the 1960s there were moderate increases, but in 1971, with the acquisition of Mirage

\footnotetext{
2 This expenditure corresponds to the amount allocated by the central government to the Ministry of National Defence, including both the resources allocated to the military forces and those for the National Police. This means that it does not take account of the contributions made by departmental, district or municipal governments, aid from other countries, or private-sector contributions.
}

warplanes and automatic weapons, EPF rose to over $3 \%$ of GDP: higher than during the conflict with Peru. Subsequently, even though relatively substantial amounts of military equipment were acquired in the 1970s, average spending dropped back again to levels below the historical average.

The purchase of Urutú and Cascabel armoured vehicles, the construction of the Bahía Málaga naval base on the Pacific coast of Colombia and the runway of the Marandúa air base in the eastern lowlands, together with the acquisition of missile corvettes in the first half of the 1980s, raised the level of spending, but only slightly above the average. The acquisition of Kfir warplanes gave rise to the last increase in the 1980s, but even so the growth rate of expenditure was below the trend level.

The 1990s marked the beginning of a new pattern of behaviour of EPF in the country. With regard to investment, the Five-Year Plan was begun in 1991, supplemented with phases I, II and III of the Energy Protection Plan. The first of these plans set investment priorities, with emphasis on maintenance programmes, in order to improve the readiness and operational quality of the Public Forces. The different phases of the Energy Protection Plan, for their part, were aimed at organizing volunteer military units ${ }^{3}$ to protect the oil and electricity sectors. The "Commotion Plan" and the "Integral Plan" were also put into effect, in 1992 and 1993, to counter the permanent offensive of the guerrilla and develop an integral war strategy to respond to the disturbances caused by the various outlaw groups. The resources provided for in these plans were for maintaining and renewing military equipment and making up shortcomings in this respect, improving the mobility of the troops, especially through the use of helicopters, and modernizing communications between the different government bodies, the military forces and the National Police.

With regard to operational expenditure, the above programmes meant the activation of a substantial number of units and the incorporation of a considerable number of personnel. Priority was also

\footnotetext{
${ }^{3}$ Paid non-conscripted soldiers.
} 
FIGURE 1

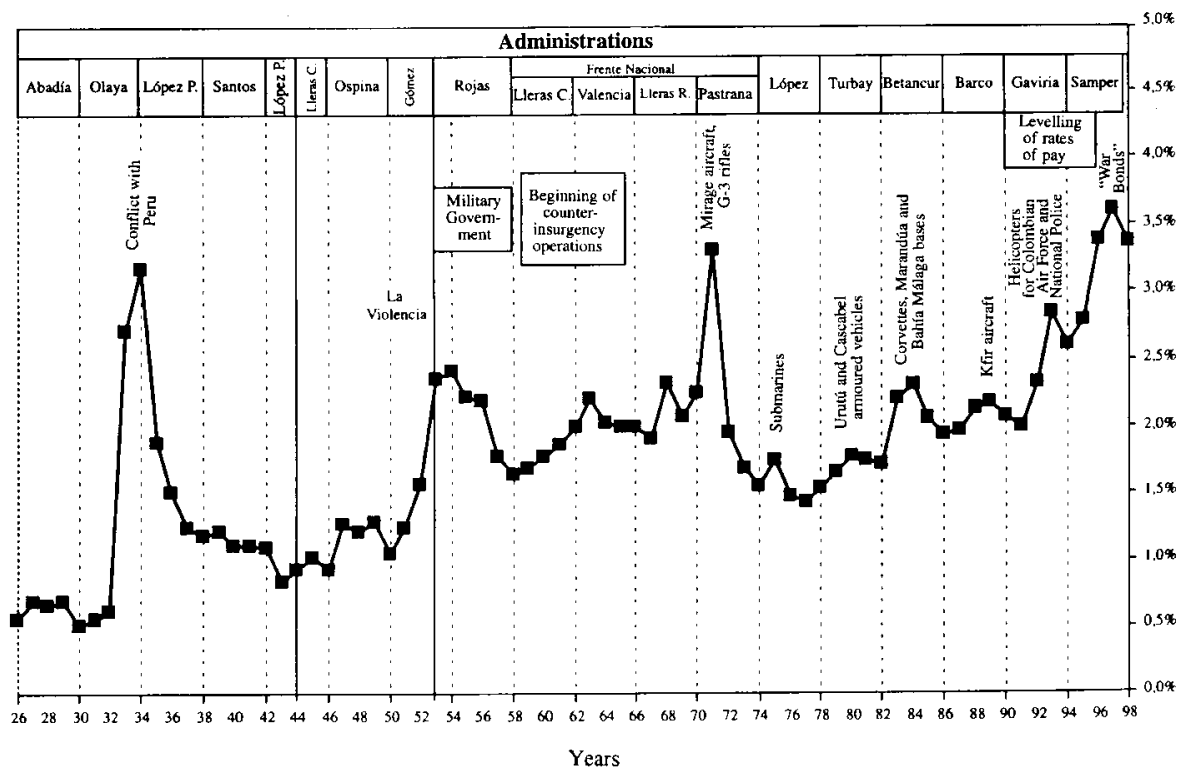

TABLE 1

Expenditure on the Public Forces (EPF)

as a percentage of GDP, 1926-1998

(By decades and historic events)

\begin{tabular}{lc}
\hline Years & Periods/events \\
& EPF/GDP \\
& $(\%)$
\end{tabular}

Average, 1926-1998

$\begin{array}{lll}\begin{array}{l}\text { 1926-1998 } \\ \text { Decades }\end{array} & \text { Period studied } & 1.8 \\ 1926-1929 & 1920 \mathrm{~s} & \\ 1930-1939 & 1930 \mathrm{~s} & 0.7 \\ 1940-1949 & 1940 \mathrm{~s} & 1.5 \\ 1950-1959 & 1950 \mathrm{~s} & 1.1 \\ 1960-1969 & 1960 \mathrm{~s} & 1.8 \\ 1970-1979 & 1970 \mathrm{~s} & 2.0 \\ 1980-1989 & 1980 \mathrm{~s} & 1.9 \\ 1990-1998 & 1990 \mathrm{~s} & 2.0 \\ \text { Historic events } & & 2.8 \\ 1926-1931 & \text { Period leading up to war } & \\ & \text { with Peru } & \\ 1933-1934 & \text { War with Peru } & 0.6 \\ 1939-1947 & \text { Second World War } & 3.0 \\ 1948-1952 & \text { "La Violencia" } & 1.1 \\ 1953-1970 & \text { Rojas and the National Front } & 1.3 \\ 1993-1998 & \text { Levelling of rates of pay } & 2.0 \\ \end{array}$

Source: Office of the Comptroller-General of the Republic and calculations by the authors. given to increasing the budgets for general expenditure (especially the purchase of equipment and supplies), strengthening intelligence activities, developing health services and improving field rations. Lastly, with regard to personal services and transfers, pay and pensions, Law No. 1992/4 was passed, placing the pay of members of the Public Forces on the same footing.

Finally, in 1997 the economy made its biggest effort in this sector since 1926. This was due to two factors: the structural upward trend in operating expenses as a result of the levelling of rates of pay in 1992, and the investment resources obtained through the Security Bonds. These bonds, also known as War Bonds, were designed in general to meet the main needs facing the sector within the framework of a counter-insurgency strategy centered on three areas: mobility, intelligence and communications.

The evolution of EPF as a percentage of GDP in the past enables us to infer its probable evolution in the future. It should be noted first of all that throughout the twentieth century (excluding the War of a Thousand Days, a civil war which took place between 1899 and 1902) EPF has displayed an oscillating but generally upward trend. Its variations can largely be explained by conjunctural factors such as conflicts or tensions with neighbouring countries, particular acquisitions of high-cost equipment or installations, or action to deal with subversion and drug 
trafficking. This pattern showed a turning point in the early 1990s, however, when the levelling of the pay of active and retired members of the Public Forces added an upward structural component to EPF.

\section{Effects of expenditure on the Public Forces}

After having verified the historical behaviour of EPF, it is vitally important to determine its main effects on the economy. Analysis of the EPF/GDP series shows an upward trend throughout the period from 1926 to 1998 (figure 2). It is estimated that the Public Forces increased their annual expenditure by $0.023 \%$ of GDP. It is important to note that overall central government expenditure (CGE) shows the same type of behaviour: according to preliminary calculations, its average annual increase was $0.156 \%$ of GDP. Central government expenditure for other purposes (CGEOP), ${ }^{4}$ which excludes the defence sector, grew by $0.134 \%$ of GDP annually.

\footnotetext{
${ }^{4}$ This expenditure also displays an upward trend, although more fluctuating, as a proportion of GDP (5.6\% in 1950 and $20.8 \%$ in 1997).
}

At first sight, the difference between the slopes would appear to indicate that defence sector expenditure is skewed in comparison with central government expenditure for other purposes. If we compare the average annual growth rates of these series, however, we see that this is not so. As a proportion of GDP, EPF grew by $1.532 \%$, while CGE and CGEOP grew by $1.250 \%$ and $1.245 \%$, respectively (table 2 and figure 3 ).

TABLE 2

Colombia: Estimated growth rates of expenditure on the Public Forces (EPF) and central government expenditure (CGE), as percentages of GDP (Annual averages)

\begin{tabular}{lccc}
\hline & $1926-1998$ & $1926-1979$ & $1980-1998$ \\
\hline EPF/GDP & 1.532 & 1.777 & 3.531 \\
CGE/GDP & 1.250 & 0.761 & 3.824 \\
CGEOP/GDP a & 1.245 & 0.642 & 3.873 \\
EPF/CGE & 0.284 & 1.016 & -0.294 \\
CGEOP/CGE & -0.003 & -0.119 & 0.049 \\
\hline
\end{tabular}

Source: Office of the Comptroller-General of the Republic and calculations by the authors.

${ }^{\text {a }}$ CGEOP $=$ Central government expenditure for other purposes (excludes EPF).

FIGURE 2

Colombia: Weight of defence sector and central government in the economy, ${ }^{\mathrm{a}}$ 1926-1998

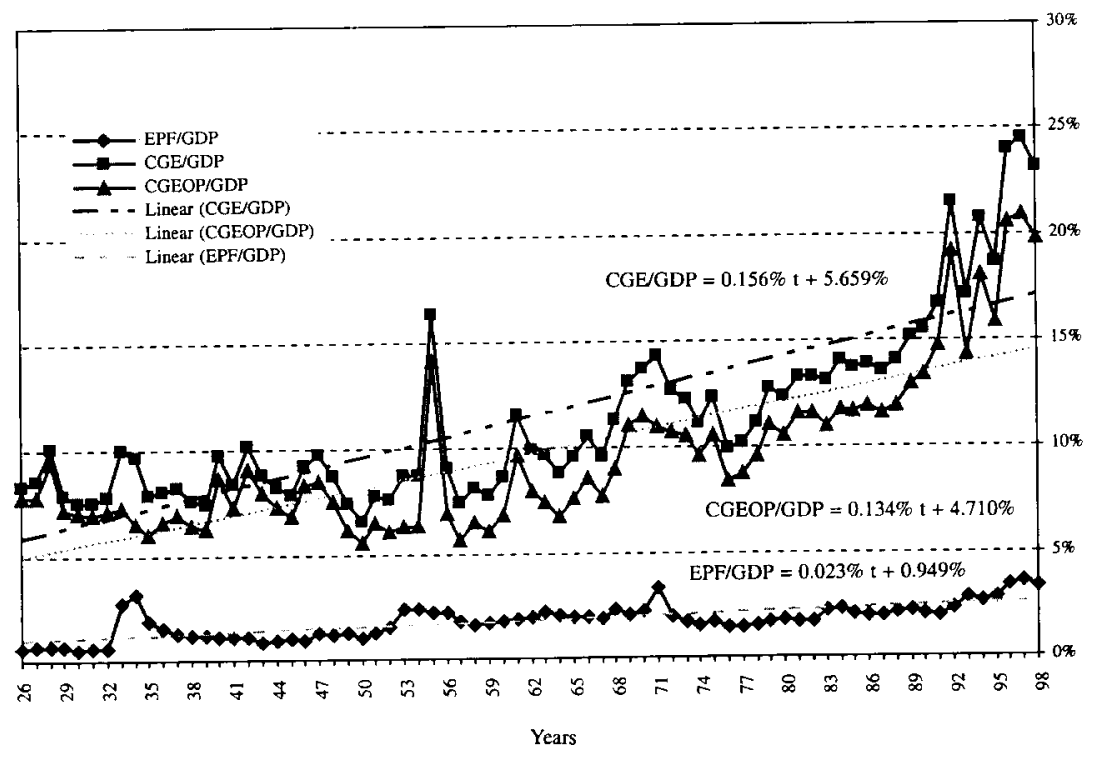

${ }^{a} \mathrm{EPF}=$ Expenditure on the Public Forces; $\mathrm{CGE}=$ Central government expenditure; $\mathrm{CGEOP}=$ Central government expenditure for other purposes. 
FIGURE 3

Colombia: Economic weight of defence sector and central government expenditure for other purposes, 1926-1998 ${ }^{\text {a }}$

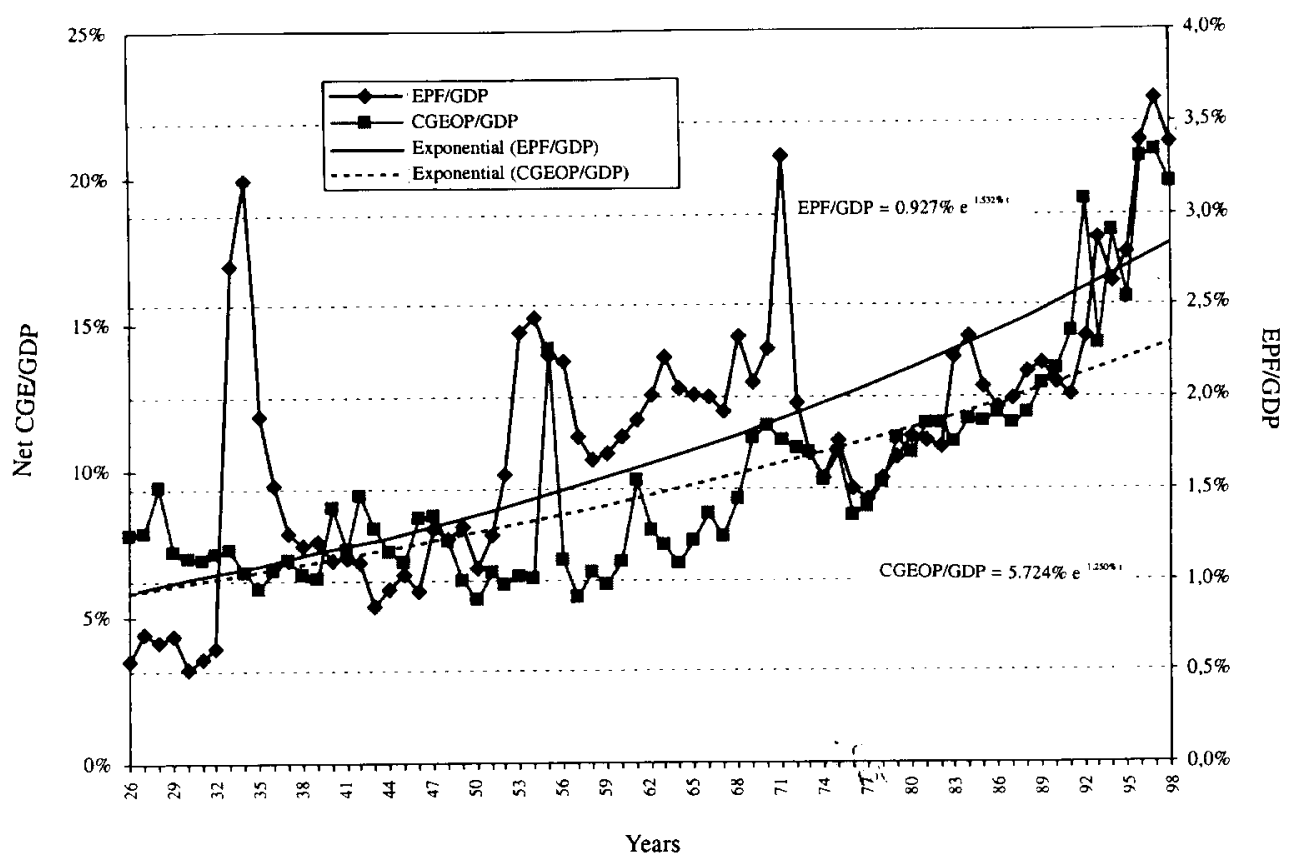

${ }^{a} \mathrm{EPF}=$ Expenditure on the Public Forces.

CGEOP $=$ Central government expenditure for other purposes.

This is explained by the fact that, on average, the government allocated more resources to the defence sector than to the other sectors. The average growth rate of EPF in central government expenditure was $0.284 \%$, while that of CGEOP was $-0.003 \%$ (figure 4 ).

From the behaviour of the relation EPF/CGE, it may be inferred that the defence sector is a restriction for CGE, because it is observed that when extra resources were allocated for non-military sectors EPF also increased its share of central government expenditure. This would explain the growing share of CGE in GDP. ${ }^{6}$

If the central government had kept its share of GDP constant (at 11.26\%, for example), then in 1998 CGEOP would have been $7.8 \%$ of GDP, not $20.9 \%,{ }^{7}$

${ }^{5}$ Causality tests show that CGEOP/CGE causes (inversely) EPF/GDP.

${ }^{6}$ Or, on the contrary, the defence sector would be a guarantor of the new expenditure.

${ }^{7}$ As long as the EPF/CGE, EPF/GDP and CGEOP/CGE series are stationary -that is to say, they vary around the mean, or tend to be self-correcting- the CGE/GDP and CGEOP/GDP ratios have a root of 1 (they are random walks and their variances tend to infinity, making it difficult to model them). but as the central government has been taking on greater responsibilities it has had to appropriate more resources from the economy.

What causal relation exists between EPF/GDP and CGEOP/GDP? Causality tests in the Granger sense show that CGEOP/GDP causes EPF/GDP directly (CGEOP/GDP is non-stationary and has a growth trend). Also, CGEOP/CGE (with a negative trend) causes EPF/GDP (inversely). However, there is no causal relation between CGEOP/GDP and CGEOP/CGE. ${ }^{8}$

Furthermore, when we analyse the average shares of either of these two variables by decades we see that there is a replacement effect. ${ }^{9}$ Examples of this are seen in the 1930s, 1950s and 1970s (table 3). In the 1960 s to the 1990 s there is a complementation effect: both variables grow, but at different rates,

\footnotetext{
8 This analysis is not fulfilled for the subperiod 1980-1998, since the trend of CGEOP/CGE changes to a growth trend (maintaining the indirect relation), so that EPF should have reduced its share in GDP.

${ }^{9}$ A replacement effect is an inverse relation between the variables.
} 
FIGURE 4

Colombia: Expenditure on the Public Forces (EPF) as a

percentage of central government expenditure (CGE), 1926-1998

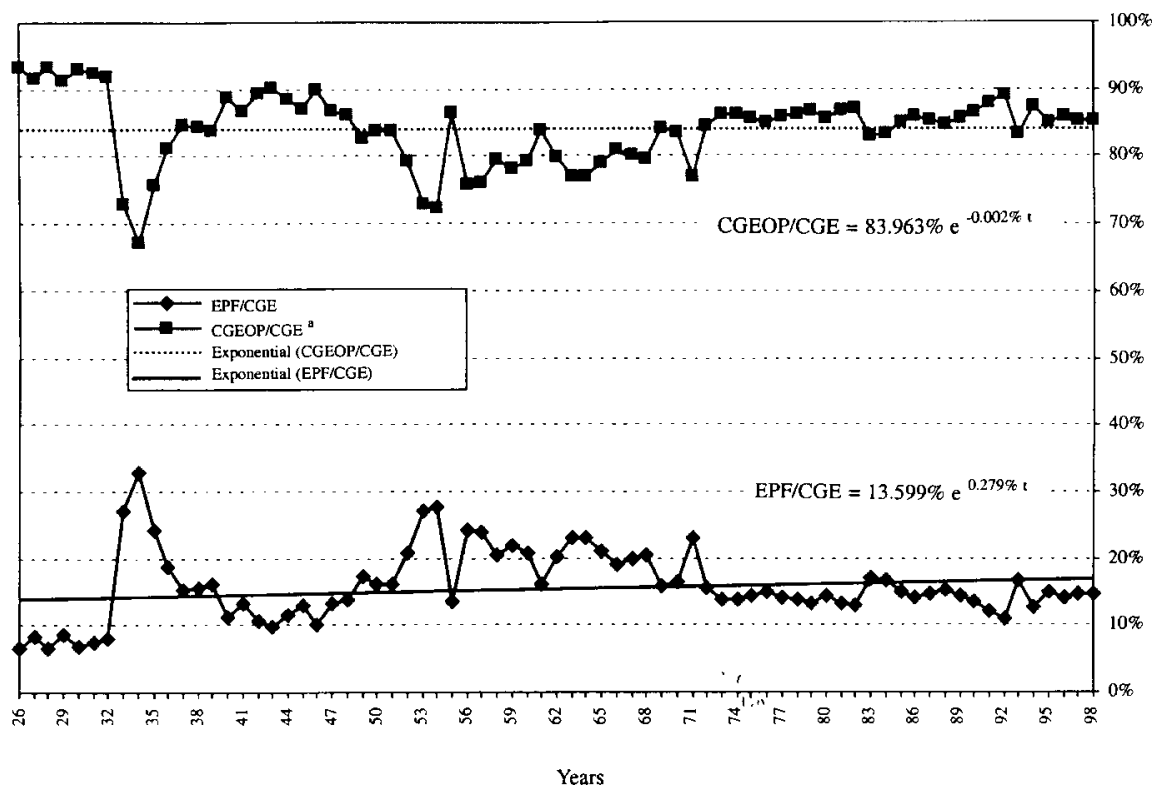

${ }^{\mathrm{a}} \mathrm{CGEOP}=\mathrm{Central}$ government expenditure for other purposes .

TABLE 3

Colombia: Behaviour of expenditure series for central government (CGE), Public Forces (EPF) and other purposes (CGEOP), by decades

(Percentages)

\begin{tabular}{|c|c|c|c|c|c|c|c|c|}
\hline Decades & EPF/CGE & $\%$ variation & EPF/GDP & $\%$ variation & CGE/GDP & $\%$ variation & CGEOP/GDP ${ }^{\mathrm{a}}$ & $\%$ variation \\
\hline $1920 s^{b}$ & 7.6 & & 0.7 & & 8.7 & & 8.1 & \\
\hline $1930 \mathrm{~s}$ & 17.3 & 127.5 & 1.5 & 124.2 & 8.2 & -6.2 & 6.7 & -16.8 \\
\hline $1940 \mathrm{~s}$ & 12.4 & -28.0 & 1.1 & -25.9 & 8.9 & 8.3 & 7.8 & 15.8 \\
\hline $1950 \mathrm{~s}$ & 21.1 & 70.1 & 1.8 & 67.4 & 8.8 & -0.2 & 7.0 & -9.7 \\
\hline $1960 \mathrm{~s}$ & 20.0 & -5.6 & 2.0 & 11.1 & 10.3 & 16.3 & 8.3 & 17.7 \\
\hline $1970 \mathrm{~s}$ & 15.3 & -23.1 & 1.9 & -7.7 & 12.0 & 17.1 & 10.2 & 23.2 \\
\hline $1980 \mathrm{~s}$ & 14.7 & -3.9 & 2.0 & 7.7 & 13.6 & 13.3 & 11.6 & 14.4 \\
\hline $1990 \mathrm{~s}^{\mathrm{c}}$ & 13.8 & -6.5 & 2.8 & 38.5 & 20.2 & 48.2 & 17.4 & 49.9 \\
\hline
\end{tabular}

Source: Office of the Comptroller-General of the Republic and calculations by the authors.

a $\mathrm{CGEOP}=$ Central government expenditure for other purposes (excludes defence).

b $1926-1929 . \quad$ c $1990-1998$.

which thus affect their shares in central government expenditure. This can only happen if the central government appropriates more resources from the GDP.

\section{a) Present composition of expenditure}

In the 1980-1998 period, the main component of EPF $(45.2 \%$ of the total) was the "personal services" item, corresponding to payment of the personnel. The "transfers" item accounted for $26.2 \%$ and corresponds basically to payments in respect of social security, pensions ${ }^{10}$ and severance benefits. The

\footnotetext{
${ }^{10}$ Allocations to retired personnel.
} 
TABLE 4

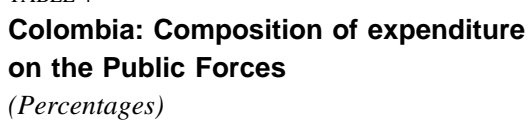

\begin{tabular}{lccc}
\hline Period & $\begin{array}{c}\text { Remuneration } \\
\text { of active and } \\
\text { retired personnel }\end{array}$ & Operations & Investment \\
\hline $1980-1998$ & 71.4 & 14.8 & 13.8 \\
$1980-1992$ & 70.0 & 13.8 & 16.4 \\
$1993-1998$ & 72.9 & 15.8 & 11.3 \\
\hline
\end{tabular}

Source: Office of the Comptroller-General of the Republic and calculations by the authors.

"general expenditure" item accounted for $14.8 \%$ of the total and covers the acquisition of goods and services needed to ensure the operation of the sector, ${ }^{11}$ and finally "investment" accounts for $13.8 \%$ of total expenditure. ${ }^{12}$ We thus see that the remuneration of active and retired personnel (personal services and transfers) represents $71.4 \%$ of total expenditure (table 4). The increase in the personal services item reflects the increase in the number of personnel, which grew by an average of $4.2 \%$ per year between 1980 and 1998 while the population only grew by an average of $2 \%$, so that a larger percentage of the population now forms part of the Public Forces (435 soldiers for every 100,000 inhabitants in 1980 and 641 in 1998).

Furthermore, in 1992, with the levelling of rates of pay and the amounts set aside for the payment of severance benefits, there was a considerable increase in expenditure on personal services and transfers. This was reflected in a restructuring of EPF, with investment being the variable most affected. ${ }^{13}$

All the foregoing was reflected in an increase in the resources allocated for the sector (figure 5), which, after having been $2.1 \%$ of GDP in the

\footnotetext{
11 A discussion is currently under way in the country as to whether this investment increases the gross capital formation of the economy. In this study it is considered that the combination of the military equipment factor (arms, aircraft, field hospitals, etc.) and the human factor generates the product which satisfies the defence and security demands of society.

${ }^{12}$ Investment has a similar weight to that of general expenditure in most years.

13 In 1997, the resources supplied to this sector by the War Bonds were equivalent to $1.45 \%$ of the regular budget for that year.
}

1980-1992 period, rose to $3.1 \%$ in $1993-1998(3.6 \%$ in 1997). Before the levelling of rates of pay, $1.4 \%$ of GDP went for the payment of active and retired personnel, $0.3 \%$ for Public Forces operations, and $0.3 \%$ for the purchase and maintenance of equipment (a total of 2.1\%). In the 1993-1998 period, however, these values went up to $2.3 \%, 0.5 \%$ and $0.4 \%$, respectively (a total of $3.2 \%$ of GDP). ${ }^{14}$

In 1997, 3.6\% of GDP went to the Public Forces, broken down as follows: $2.4 \%$ for payment of personnel, $0.5 \%$ for operations, and $0.7 \%$ for investment. It is expected that in the future this sector will receive still greater resources from the economy, amounting to between $4.1 \%$ and $5.3 \%$ of $\mathrm{GDP}^{15}$ in $2005^{16}$ (figure 6).

b) Fiscal restrictions of the central government

With the 1991 administrative decentralization it was expected that the central government would be freed from direct responsibilities, so that its level of expenditure would go down. Contrary to what had been expected, however, the new commitments imposed on it by the 1991 Constitution caused the central government share in GDP to increase considerably, reaching $24.5 \%$ in 1997 (or $17.9 \%$ if debt service is excluded). Such an increase is not a good thing for the economy, and it needs to be reduced in the short term. ${ }^{17}$

If the defence sector does not change its behaviour (figure 7), then very soon the central government will have to devote a growing proportion of its expenditure to it (up to $17.2 \%$ in 2002). ${ }^{18}$ This means that the economy will only be able to allocate a maximum of $3.5 \%$ of $\mathrm{GDP}^{19}$ (figure 8 ). Between this behaviour and the projection of EPF there is a growing

\footnotetext{
14 Although greater resources have been allocated to the sector overall, the "general expenditure" and "investment" items have each fluctuated between $0.2 \%$ and $0.5 \%$ of GDP.

15 Two econometric models were applied in which the GDP (lagged by one and four years) is the explanatory variable.

16 Using an analysis based on a long-term series, this range increases to $6.7 \%$ and $6.8 \%$ of GDP.

17 In the following analysis it was assumed that the level of CGE would go down by 4 percentage points of GDP in the next three years.

${ }^{18}$ EPF was projected by applying the error correction mechanism model to the differences between the logarithms of the variables and the adjustment coefficient of the cointegration equation (see the statistical and econometric annex).

${ }^{19}$ It should be noted that this level of expenditure as a proportion of GDP cannot be maintained over time because it would mean constantly reducing the share of central government expenditure in the economy, until a point where that expenditure would go exclusively to the defence sector.
} 
FIGURE 5

Colombia: Share of expenditure on the Public Forces in GDP, 1980-1998

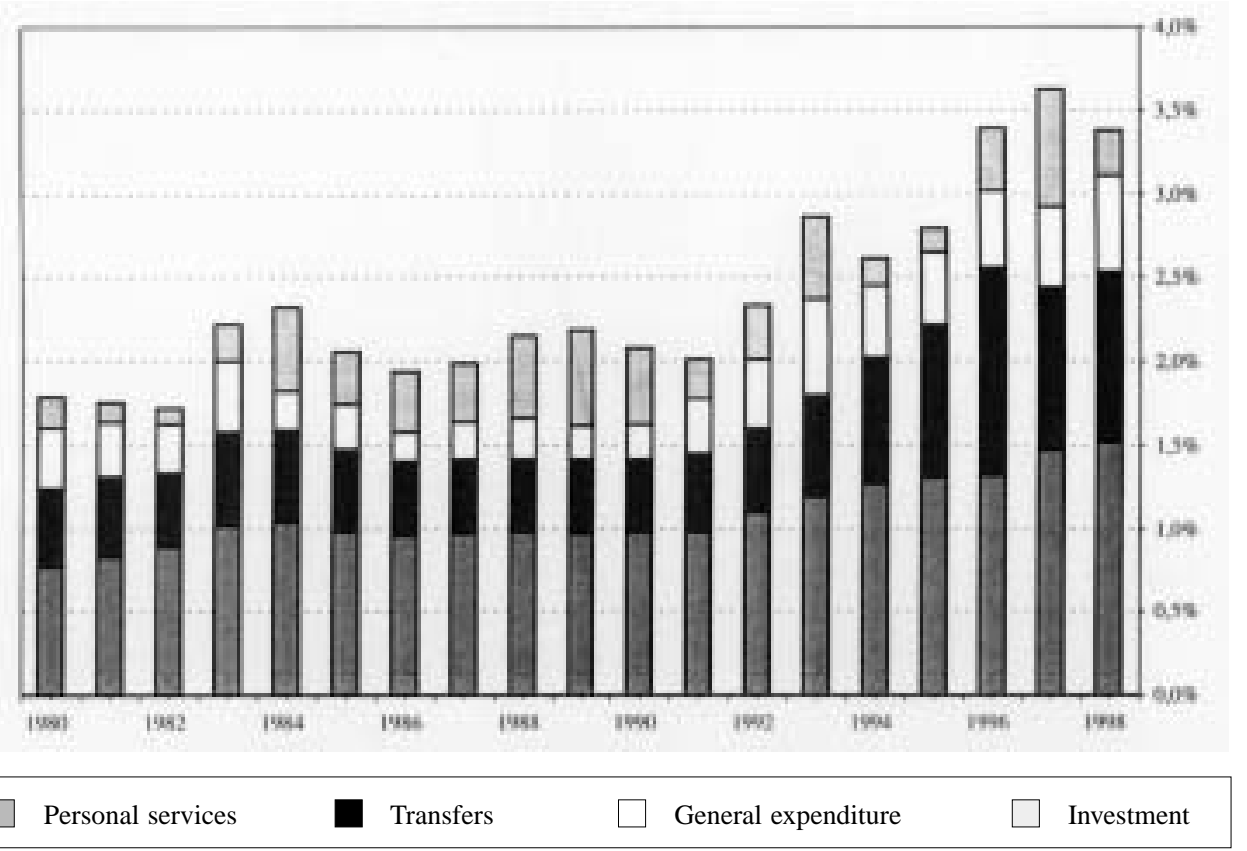

FIGURE 6

Colombia: Past evolution and future projections of expenditure on the Public Forces (EPF), as a proportion of GDP, 1980-2004

(Short-term analysis)

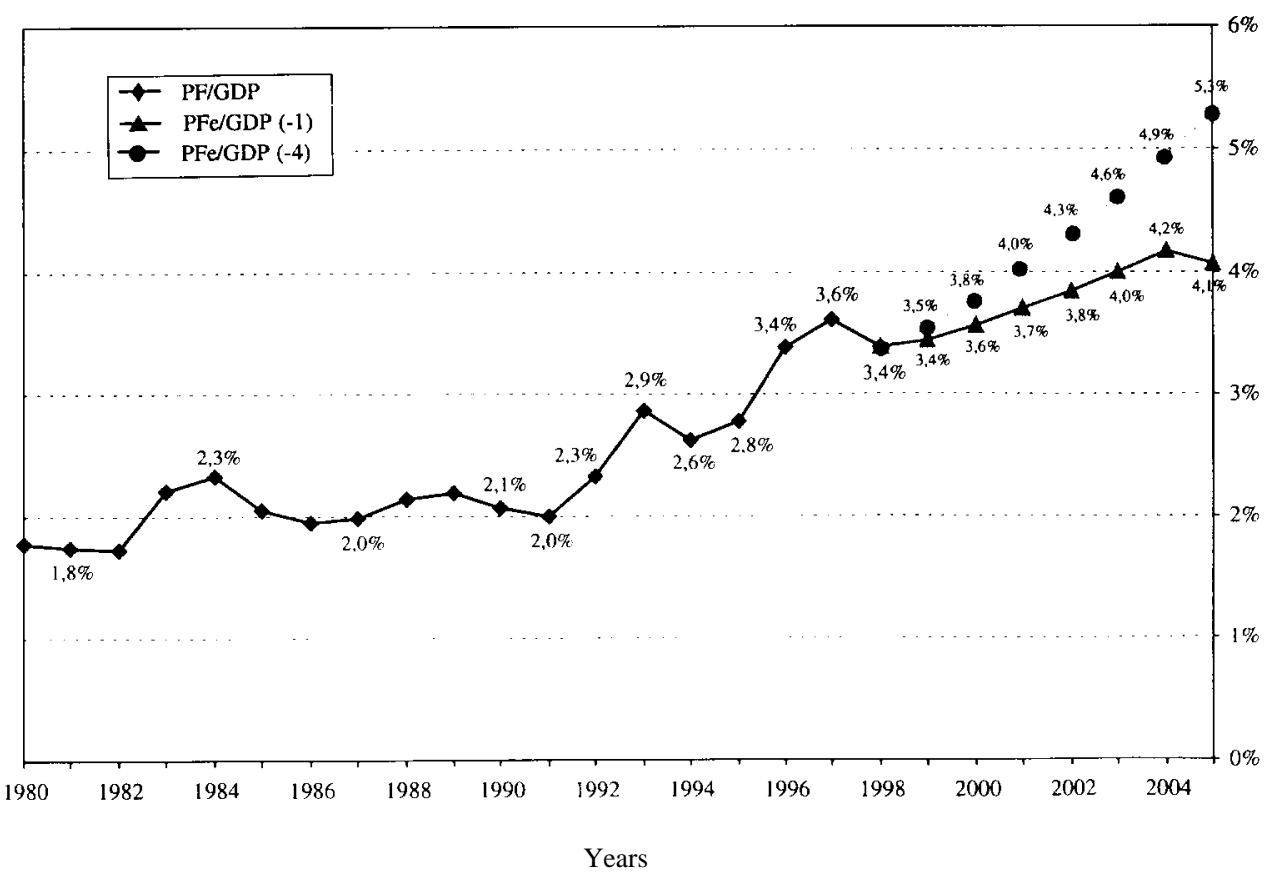

MILITARY EXPENDITURE IN COLOMBIA: MACROECONOMIC AND MICROECONOMIC ASPECTS • YANETH GIHA TOBAR, HÉCTOR RIVEROS REYES AND ANDRÉS SOTO VELASCO 
FIGURE 7

Colombia: Past behaviour and future estimates of expenditure on the Public Forces (EPF), as a proportion of central government expenditure (CGE), in the event of a cut in CGE as a proportion of GDP, 1980-2002

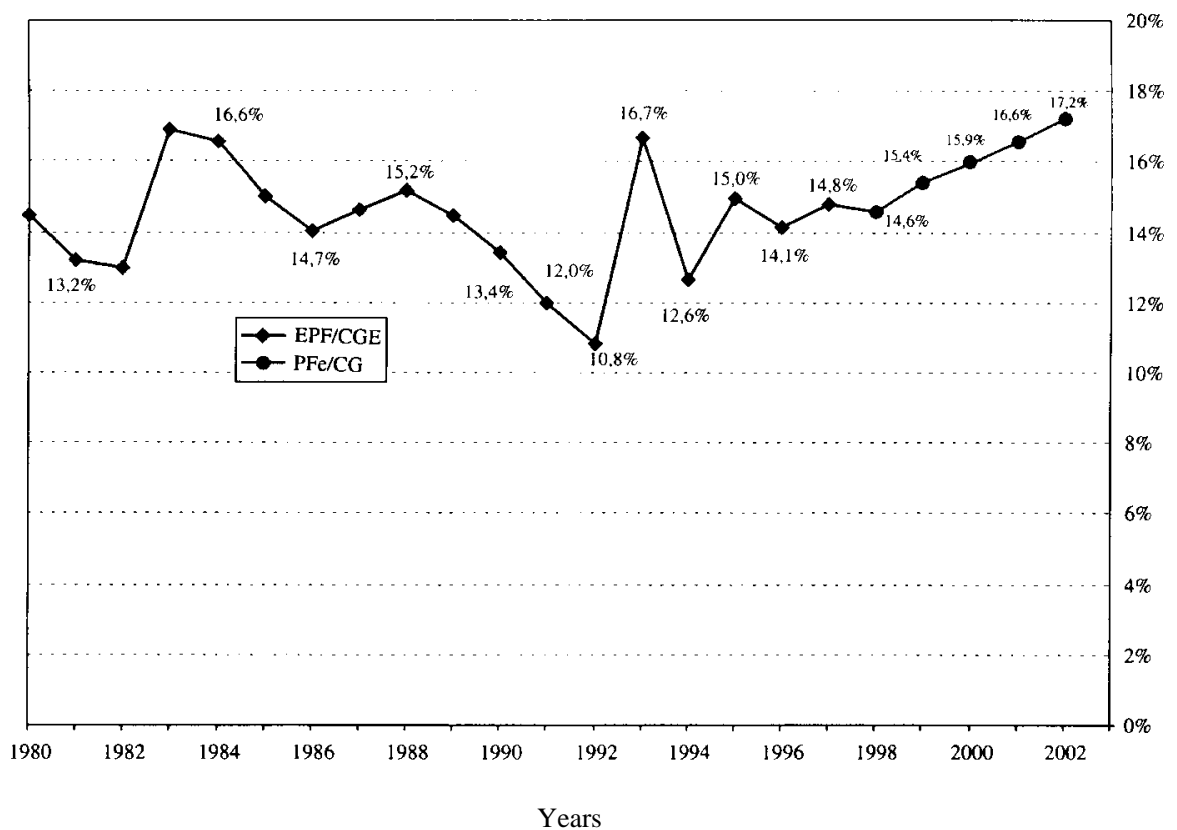

Colombia: Behaviour of central government expenditure (CGE) and expenditure on the Public Forces (EPF), as proportions of GDP, in the event of restriction of central government expenditure, 1980-2005

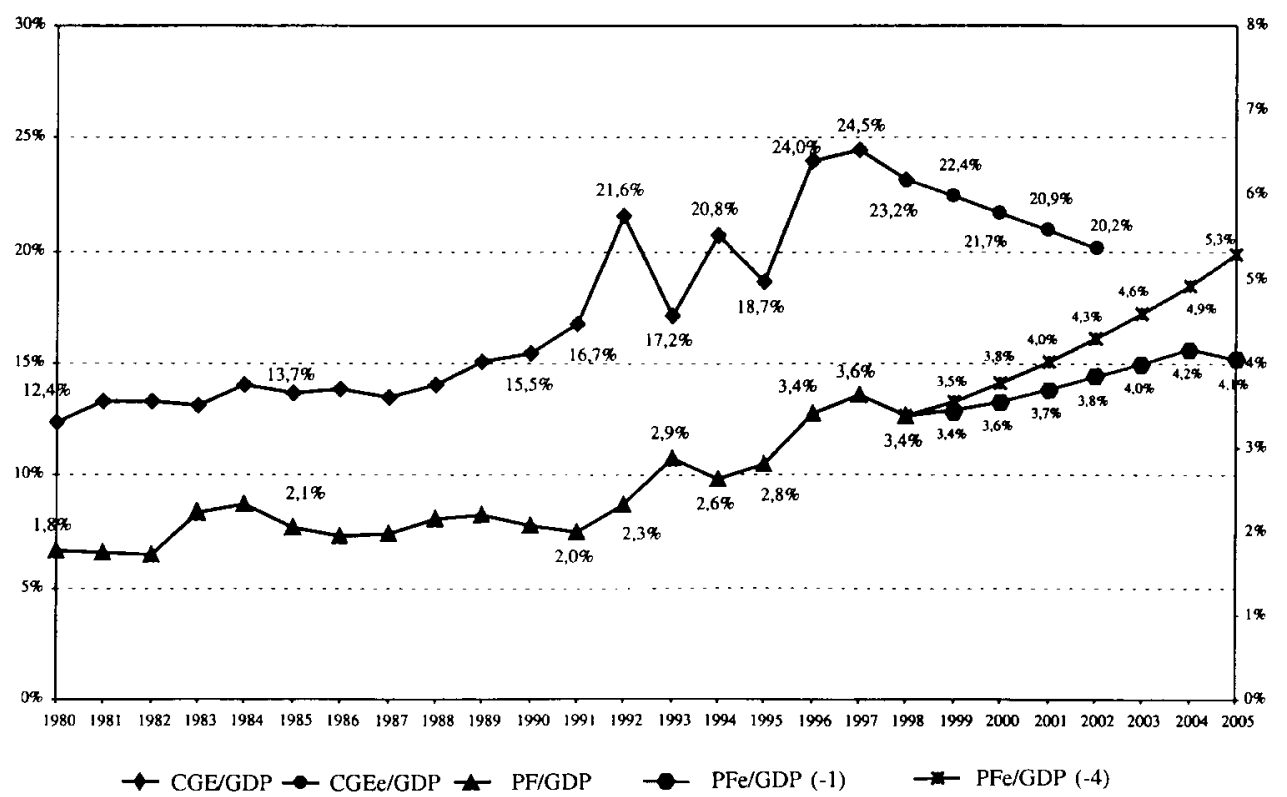

MILITARY EXPENDITURE IN COLOMBIA: MACROECONOMIC AND MICROECONOMIC ASPECTS • YANETH GIHA TOBAR, HÉCTOR RIVEROS REYES AND ANDRÉS SOTO VELASCO 
deficit calculated at $0 \%$ to $0.1 \%$ of GDP in 1999 , $0.1 \%$ to $0.3 \%$ in $2000,0.2 \%$ to $0.6 \%$ in 2001 , and $0.4 \%$ to $0.8 \%$ in 2002 .

From the econometric standpoint, there is evidence of causality between GDP and EPF. In addition, the long-term models reflect a direct relation, although this causality is not fulfilled inversely. It may be deduced from these results that EPF does not generate growth of GDP, but on the other hand it cannot be asserted that a reduction in EPF will bring an increase in GDP.

As mentioned earlier, the factor which has determined EPF growth in the past has been the purchase of equipment and installations: that is to say, the adjustment variables of the Public Forces budget have been the investment and general expenditure items. At the same time, it may be noted that although there has been an increase in the proportion of GDP devoted to EPF, these particular items have remained within relatively narrow margins. Consequently, if the growing share of payroll expenses is combined with less than proportional growth of total expenditure, the space for investment may become increasingly small in the future.

Thus, if a ceiling is fixed for EPF as a proportion of GDP, the internal dynamics of expenditure will cause payroll expenditure to crowd out investment, if the share of general expenditure in GDP remains constant.

These results highlight the need to make fundamental reforms in the defence sector in order to help reduce central government expenditure. In view of the fact that every year more personnel are incorporated into the sector, which naturally calls for more resources, then if the present trend continues the percentage of GDP devoted to the Public Forces will only cover the pay and pensions of their active and retired personnel.

\section{V}

\section{The efficiency of military spending}

Analysis of the internal composition of EPF in Colombia shows that the present structure of the Public Forces needs to be reviewed for reasons of efficiency. The plans and programmes carried out in the past were generally aimed at providing more of "the mixture as before". This has had macroeconomic repercussions because there has not been a policy on expenditure which has made it possible to keep EPF within fiscally sustainable limits.

However, rather than going more deeply into the possible impact of military spending on the economy, what is vitally important is to go more deeply into the present cost structure of the country's defence and security apparatus. As already noted, the monetary resources allocated to the sector are not necessarily reflected in greater capacity to provide security. Although the sector represents quite a heavy budgetary burden for the State, its functions are being limited by its own internal structure. Thus, in order to understand the dynamics of the sector and its macroeconomic repercussions, it is essential to analyse the microeconomic aspects of EPF.

In view of this, it would be desirable to begin the cost reduction process by making changes in the areas of personnel management and administration of physical resources. Above all, it is necessary to examine the defence and security sector by considering two aspects of fundamental importance for deciding on lines of action. The first, which is of an organizational nature, is the ratio of operational personnel to administrative and support personnel. The second, which is a matter of implementation, is the way the action of the Public Forces is applied. These two aspects determine the possibility of strengthening these forces in a context of fiscal constraints.

The combat/support ratio represents the number of men needed to provide support for one single soldier in a combat area. In Colombia, there are currently approximately eight support personnel for each combat soldier. If this ratio were substantially modified, the Public Forces would work more efficiently. International parameters indicate that this ratio should be around 3:1. A lighter and faster-moving structure would make it possible to increase fighting power.

The structure of the sector therefore needs to be reappraised. The decisions taken to reduce the administrative personnel (to a support/combat ratio of 
3:1, for example) can be of two types, which are not necessarily mutually exclusive. On the one hand, the decision could be taken to apply a policy of reduction of the number of personnel, leading to a reduction of the administrative component of military units and a change in the officer/soldier ratio. This option could reduce the direct costs of military forces, but would not necessarily mean an increase in fighting power; moreover, it would involve greater indirect costs, because it would lead to the early retirement of pensionable personnel and it would be necessary to provide incentives for voluntary resignation or, at least, some viable mechanisms to link up with the labour or educational markets.

On the other hand, it could be decided to carry out a process of reorganization within the Public Forces. This would make it possible to at least double their fighting power with the same personnel. This would create a more efficient structure and reduce the growth rate of the number of personnel, at least in the medium term, which would be more in keeping with the macroeconomic fiscal constraints referred to earlier.

Let us now consider the attack/defence ratio, which is the ratio between the attacking and defending forces. Some of the main signals received by Colombian public opinion regarding the public order situation are reports of guerrilla attacks on isolated military posts, ambushes of patrols, and the occupation of towns or villages. These incidents summarize the military interaction between the Public Forces and the guerrilla. These kinds of armed encounters could therefore serve as a unit of analysis for gaining a realistic idea of the confrontation between the regular forces and the subversives.

If we compare the total number of men in the subversive groups and in the Public Forces, the balance of power would appear to lie with the latter. However, this ratio of numbers of men is no use for an objective analysis, since the combats are never between the whole of the Public Forces and the whole of the guerrilla. Guerrilla war consists precisely of avoiding a confrontation of this type. Consequently, the ratio of forces must be determined in the con- text of isolated combats preferred by the subversives. In these, we have seen that the guerrilla usually has greater fighting power than the Public Forces, which shows the ineffectiveness of the policy of maintaining a dispersed presence of the latter in areas of conflict. Rather than showing their presence, the Public Forces should concentrate their efforts on making preparations so as to ensure that they have a fighting potential greater than that of the illegal armed groups in these isolated areas, either by becoming more effective in defence or developing a suitable structure for attack. The decision to pursue one or the other of these objectives will depend on the region where the forces are operating, the support given by the community, and the type of outlaw armed groups present in the region.

In order to improve the combat/support ratio and modify the defence/attack ratio, it is clear that it is not necessary to increase the number of personnel, but to reorganize the existing ones. This calls for decisions on two fronts: a change in the present structure of the Public Forces so that there are more combat personnel, and a change in the present attack/defence ratio in order to establish strong points, either as a defensive force or as an offensive one. Past experience has shown that the political need for the Public Forces to show themselves throughout the national territory has been militarily inefficient and economically unsustainable.

The restructuring of the personnel of the Public Forces is a sufficient condition for reducing the pressure of this sector on fiscal resources (efficiency) and a necessary condition for improving results in the military field (efficacy). It will not be possible to improve the results unless the provision of equipment is reviewed also. It is not a question of acquiring more of the same kind of equipment, but of providing the personnel with the right equipment for the present type of combat. This improved provision of equipment must take place both in the operational and the support areas, because if this is not done it will be more difficult to transfer support personnel to combat duties. 


\section{VI}

\section{Conclusions}

Analysis of the dynamics of military spending in Colombia reveals that although the State has devoted relatively few resources to national defence in the twentieth century as a whole, this expenditure increased significantly in the 1990s. Yet if we consider the principles that should justify such spending, it is clear that the Colombian Public Forces are not achieving their objectives in terms of internal security.

The Colombian State is faced with the need to improve the efficiency of the Public Forces for providing citizens with security, while at the same time reducing the cost structure of these forces. These objectives may seem contradictory, but it is politically and militarily essential for the Public Forces to recover their monopoly of the use of arms and it is economically indispensable that they should do so with a more rational cost structure. If this is not done, EPF will be truly unproductive, as the deterioration of the country's democratic institutions will continue and there will be serious imbalances in the State finances.

In the present article, we maintain that it is not enough simply to analyse the macroeconomic impact of a society's expenditure on defence and security. It is essential to go further and analyse the detailed composition of that expenditure, in order to provide a real basis for both macroeconomic and microeconomic analysis. The present composition of this expenditure in Colombia gives grounds for thinking about the difficulties that may be encountered in trying to reduce it.

It can be argued that it is little use having the public finances in order if society itself is not likewise in order. In Colombia, with the current form of expenditure on the Public Forces, it is not likely that the legitimacy of the State can be consolidated, but it is very likely that there will be a deterioration in the public finances. The projection of expenditure on the Public Forces for the immediate future reveals an explosive rate of growth which would bring it to over $5 \%$ of GDP by the year 2005 .

Such results are incompatible with the required readjustment of the public finances, which calls for a radical reduction in central government spending in the short term. The present structure of expenditure is not compatible with sound fiscal policy. On the other hand, fixing a ceiling on the percentage of GDP to be devoted to the Public Forces does not represent an efficient solution to the problem of the growth in EFP unless reforms are also made in its internal dynamics; as we saw earlier, the upward trend in this expenditure, due to payroll-linked factors, would crowd out investment and operating expenditure to such a point that the available resources would only cover pay and pensions. A measure that would indeed generate savings in the budget of the Ministry of National Defence, however, would be the adoption of reforms in the following areas: i) the dynamics of the budget and the process of acquisitions, and ii) management of personnel and physical installations.

The most significant savings in the defence sector are necessarily associated with personnel management. Expenditure on this item accounts for $73 \%$ of defence and security spending. It is therefore essential to undertake a review of the whole personnel management system. In this respect, consideration could be given to such measures as: i) modifying the system of pay and allowances; ii) increasing retirement age; iii) reducing the number of personnel, and iv) changing the ratio between combat forces and support and administrative personnel.

Modifying the system of pay and allowances is the most radical recommendation, since it would involve the incorporation of Ministry of National Defence personnel into the general social security system. Although it would be the most direct solution to the structural problem, it is also the most unlikely, because of its inherent political difficulties. Reduction of the number of active personnel through early retirement programmes is the most viable option. It is also imperative to improve the ratio between combat forces and support and administrative personnel, since this is the easiest way of increasing fighting power with the current number of personnel.

In order to solve the personnel problems it will be necessary to take very far-reaching decisions, each of which will have profound political, military, 
economic and social repercussions. The adoption of any of these decisions will depend to a large extent on such broad considerations as the state of the economy, the political climate, public opinion or the prevailing security situation. Nevertheless, these problems must necessarily be tackled and settled in a clear manner, for the sake of the security and economic welfare of the country.

The problem deriving from the internal conflicts in the country will not be solved by reducing the budget of the Ministry of National Defence. It is an inevitable fact that military spending will continue to exist and that internal security and external defence will continue to require resources that must be provided. The country is investing in this just as a citi- zen invests in an insurance policy. Consequently, the coverage must be effective and must be as broad as possible.

In this article we have pointed out that, because of the present cost structure of the country's security and defence apparatus, increasing the monetary resources allocated to it is not necessarily reflected in greater capacity to provide security. There are many areas where ways of multiplying the effect of each peso invested in national security could be explored. Coming to grips with the conflict, however, requires a strong political will and a determined attitude on the part of society at large, as well as the availability of material and financial resources.

(Original: Spanish)

\section{Annex. Statistical and econometric results}

FIGURE A1

Colombia: The Public Forces, as a proportion of population and GDP, 1950-1998 ${ }^{\text {a }}$
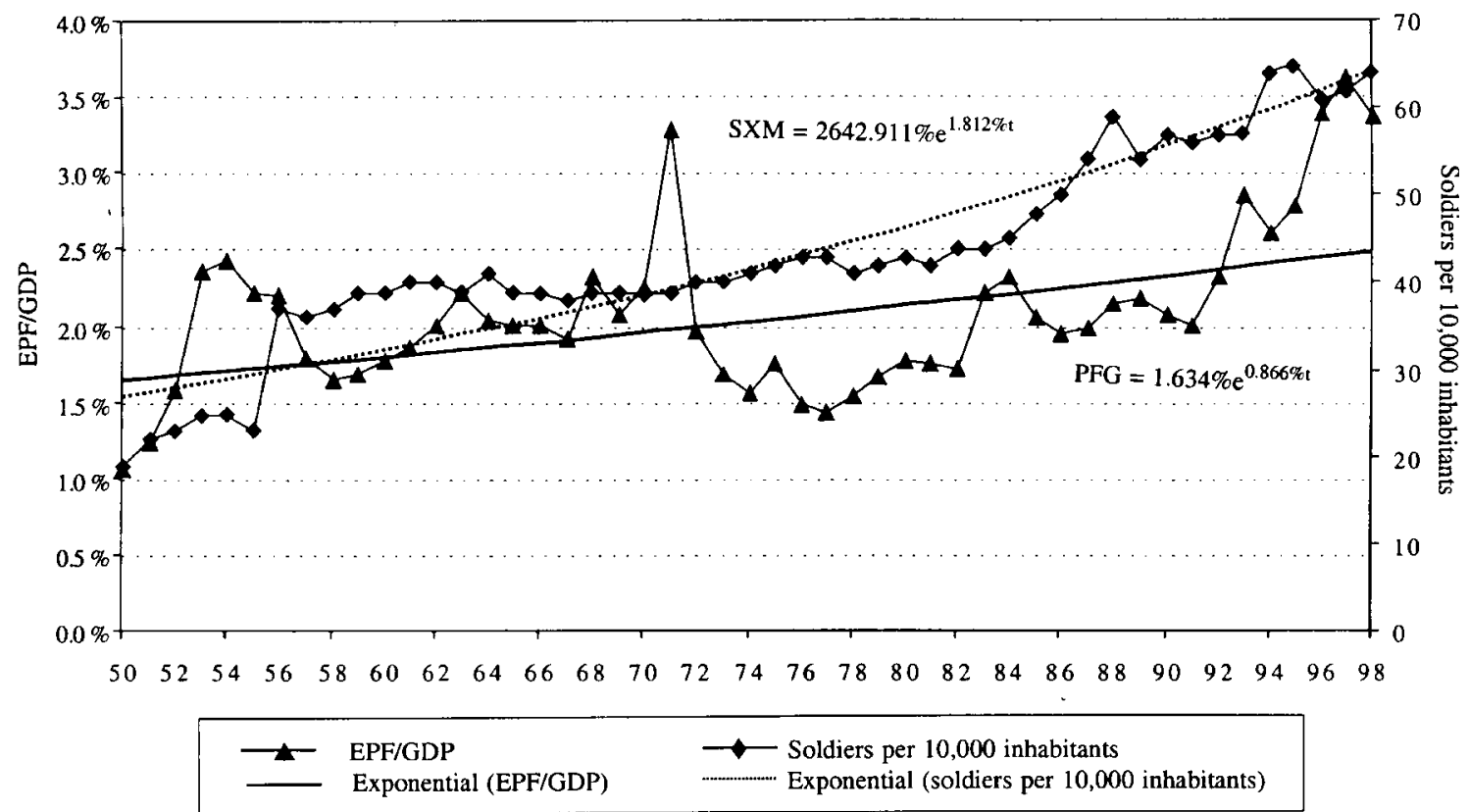

Source: Office of the Comptroller-General of the Republic of Colombia.

${ }^{\mathrm{a}} \mathrm{PFG}=$ Expenditure on the Public Forces as a proportion of GDP (EPF/GDP).

SXM $=$ Soldiers per 10,000 inhabitants.

MILITARY EXPENDITURE IN COLOMBIA: MACROECONOMIC AND MICROECONOMIC ASPECTS • YANETH GIHA TOBAR, HÉCTOR RIVEROS REYES AND ANDRÉS SOTO VELASCO 
TABLE A1

Colombia: Composition of expenditure on the Public Forces

(Percentages)

\begin{tabular}{|c|c|c|c|}
\hline & $\begin{array}{l}\text { Remune- } \\
\text { ration }\end{array}$ & Operations & Investment \\
\hline 1980 & 69.1 & 20.7 & 10.2 \\
\hline 1981 & 74.4 & 19.1 & 6.5 \\
\hline 1982 & 77.3 & 16.9 & 5.7 \\
\hline 1983 & 71.0 & 19.3 & 9.7 \\
\hline 1984 & 68.3 & 10.3 & 21.4 \\
\hline 1985 & 71.7 & 12.7 & 15.5 \\
\hline 1986 & 72.3 & 9.0 & 18.6 \\
\hline 1987 & 71.5 & 11.0 & 17.5 \\
\hline 1988 & 65.9 & 11.5 & 22.6 \\
\hline 1989 & 64.8 & 9.3 & 26.0 \\
\hline 1990 & 67.8 & 10.0 & 22.2 \\
\hline 1991 & 72.4 & 16.2 & 11.3 \\
\hline 1992 & 68.3 & 17.6 & 14.1 \\
\hline 1993 & 62.8 & 20.3 & 16.9 \\
\hline 1994 & 77.0 & 16.8 & 6.2 \\
\hline 1995 & 79.6 & 15.4 & 5.0 \\
\hline 1996 & 75.5 & 13.5 & 11.1 \\
\hline 1997 & 67.3 & 13.5 & 19.2 \\
\hline 1998 & 75.1 & 16.9 & 7.9 \\
\hline 1980-1998 & 71.4 & 14.8 & 13.8 \\
\hline 1980-1989 & 70.2 & 13.4 & 16.4 \\
\hline 1990-1998 & 72.1 & 15.6 & 12.3 \\
\hline 1980-1992 & 70.0 & 13.8 & 16.2 \\
\hline 1993-1998 & 72.9 & 15.8 & 11.3 \\
\hline
\end{tabular}

Source: Office of the Comptroller-General of the Republic of Colombia.

\section{TABLE A2 \\ Colombia: Share of expenditure on the Public Forces in GDP}

(Percentages)

\begin{tabular}{|c|c|c|c|c|}
\hline & $\begin{array}{l}\text { Remune- } \\
\text { ration }\end{array}$ & Operations & Investment & Total \\
\hline 1980 & 1.2 & 0.4 & 0.2 & 1.8 \\
\hline 1981 & 1.3 & 0.3 & 0.1 & 1.8 \\
\hline 1982 & 1.3 & 0.3 & 0.1 & 1.7 \\
\hline 1983 & 1.6 & 0.4 & 0.2 & 2.2 \\
\hline 1984 & 1.6 & 0.2 & 0.5 & 2.3 \\
\hline 1985 & 1.5 & 0.3 & 0.3 & 2.1 \\
\hline 1986 & 1.4 & 0.2 & 0.4 & 1.9 \\
\hline 1987 & 1.4 & 0.2 & 0.3 & 2.0 \\
\hline 1988 & 1.4 & 0.2 & 0.5 & 2.1 \\
\hline 1989 & 1.4 & 0.2 & 0.6 & 2.2 \\
\hline 1990 & 1.4 & 0.2 & 0.5 & 2.1 \\
\hline 1991 & 1.5 & 0.3 & 0.2 & 2.0 \\
\hline 1992 & 1.6 & 0.4 & 0.3 & 2.3 \\
\hline 1993 & 1.8 & 0.6 & 0.5 & 2.9 \\
\hline 1994 & 2.0 & 0.4 & 0.2 & 2.6 \\
\hline 1995 & 2.2 & 0.4 & 0.1 & 2.8 \\
\hline 1996 & 2.6 & 0.5 & 0.4 & 3.4 \\
\hline 1997 & 2.4 & 0.5 & 0.7 & 3.6 \\
\hline 1998 & 2.5 & 0.6 & 0.3 & 3.4 \\
\hline 1980-1998 & 1.8 & 0.4 & 0.3 & 2.5 \\
\hline 1980-1989 & 1.4 & 0.3 & 0.3 & 2.0 \\
\hline 1990-1998 & 2.1 & 0.5 & 0.4 & 2.8 \\
\hline 1980-1992 & 1.4 & 0.3 & 0.3 & 2.1 \\
\hline 1993-1998 & 2.3 & 0.5 & 0.4 & 3.1 \\
\hline
\end{tabular}

Source: Office of the Comptroller-General of the Republic of Colombia.

\section{Bibliography}

Abell, J. (1988): Defense spending and unemployment rates: An empirical analysis disaggregated by race, Journal of Conflict Resolution, vol. 32, No. 1, Dorchester, U.K., Dorset Press, March.

Ball, N. (1983): Defense and development: A critique of the Benoit study, Economic Development and Cultural Change, vol. 31, No. 3, Chicago, Illinois, The University of Chicago.

-(1986): Gastos militares, relaciones económicas internacionales y distensión, Comercio exterior, vol. 36, No. 12, Mexico City.

(1988): Security and Economy in the Third World, Princeton, New Jersey, Princeton University Press.
Bayoumi, T., D. Hewitt and S. Symansky (1993): The Impact of Worldwide Military Spending Cuts on Developing Countries, IMF working paper, No. 86, Washington, D.C., International Monetary Fund (IMF), November.

Beenstock, M. (1993): International patterns in military spending, Economic Development and Cultural Change, vol. 41, No. 3, Chicago, Illinois, The University of Chicago.

Benoit, E. (1973): Defense and Economic Growth in Developing Countries, Lexington, Massachusetts, Lexington Books.

Benoit, E. and K. Boulding (1963): Disarmament and the Economy, New York, Harper and Row. 
Borner, S., A. Brunotti and B. Weder (1992): Institutional Obstacles to Latin American Growth, Occasional papers, No. 24, Panama City, International Center for Economic Growth (ICEG).

Brito, D. and M. D. Intriligator (1989): An economic model of guerrilla warfare, International Interactions, vol. 15, No. 3.

Brommelhorster, J. (1996): Changing Priorities of Military Expenditures and the Results of the Peace Dividend, Bonn, Germany, Bonn International Center for Conversion.

Carranza, M. (1986): El desarme y el desarrollo mundial desde la perspectiva latinoamericana, Comercio exterior, vol. 36, No. 12, Mexico City, December.

Colombia, Ministry of Finance, Commission on Public Expenditure (1986): Informe final 1986, Santafé de Bogotá.

Colombia, Ministry of National Defence (1991): Plan quinquenal para la Fuerza Pública: 1992-1996, Documento CONPES, No. 2570, Santafé de Bogotá, National Council on Economic and Social Planning (CONPES), December.

(1994): Memoria al Congreso, Santafé de Bogotá.

(1995a): La defensa nacional y las fuerzas militares, Documento CONPES, No. 2824, Santafé de Bogotá, CONPES, November.

- (1995b): Modernización de la Policía Nacional en el marco del plan de seguridad ciudadana, Documento CONPES, No. 2771, Santafé de Bogotá, CONPES, March.

Comisión de Racionalización del Gasto y de las Finanzas Públicas (1997): Defensa, seguridad ciudadana y gasto público, Santafé de Bogotá.

Davis, P. K. (1994): New Challenges for Defense Planning. Rethinking How Much is Enough, Santa Monica, California, Rand.

Deger, S. (1986): Military Expenditure in Third World Countries, London, Routledge \& Kegan Paul.

- (1992): Military expenditure and economic development: Issues and debates, Military Expenditure and Economic Development, World Bank discussion papers, No. 185, Washington, D.C., World Bank.

Dunne, P. (1990): The political economy of military expenditure: An introduction, Cambridge Journal of Economics, vol. 14, No. 4, Cambridge, U.K., Academic Press Limited, December.

Frederiksen, P. and R. Looney (1982): Defense expenditures and economic growth in developing countries: Some further empirical evidence, Journal of Economic Development, No. 7, July.

Gabriel, R. and P. Savage (1978): Crisis in Command. Mismanagement in the Army, New York, Hill and Wang.

Gansler, J. (1991): Affording Defense, Cambridge, Massachusetts, The MIT Press.
Guio Rodríguez, E. A. (1996): Impuesto de guerra: por una sola vez... ¿otra vez?, La semana económica de la ASOBANCARIA, No. 63, Santafé de Bogotá, Asociación Bancaria (ASOBANCARIA).

Hayes, M. (1976): Policy consequences of military participation in politics: An analysis of tradeoffs in Brazilian federal expenditures, Comparative Public Policy, New York, Wiley.

Heller, P. and J. Diamond (1990): International Comparisons of Government Expenditure Revisited: The Developing Countries, 1975-86, IMF occasional paper, No. 69, Washington, D.C., IMF, April.

Hewitt, D. (1991): Military Expenditure: International Comparison of Trends, IMF working paper, No. 54, Washington, D.C., IMF, May.

-(1993): The Reasons Behind the Post-1985 Fall in World Military Spending, IMF working paper, No. 18, Washington, D.C, IMF, May.

Hoffman, B. and J. Morrison Taw (1992): A Strategic Framework for Countering Terrorism and Insurgency, Santa Monica, California, Rand.

Hooker, R. (1993): Maneuver Warfare: An Anthology, California, Presidio Press.

Kaun, D. (1988): War and Wall Street: The impact of military conflict on investor attitudes, Journal of Conflict Resolution, vol. 32, No. 1, Dorchester, U.K., Dorset Press, March.

Klein, L. (1986): El desarme y el desarrollo socioeconómico, Comercio exterior, vol. 36, No. 12, Mexico City, December.

Knight, M., N. Loayza and D. Villanueva (1996): The Peace Dividend: Military Spending Cuts and Economic Growth, Staff papers, vol. 43, No. 1, Washington, D.C., IMF, March.

Leger, R. (1993): World Military and Social Expenditures, Washington, D.C., U.S. Arms Control and Disarmament Agency, U.S. Government Printing Office.

Leontief, W. and F. Duchin (1983): Military Spending, Oxford, U.K., Oxford University Press.

Looney, R. E. (1986): The Political Economy of Latin American Defense Expenditures. Case Studies of Venezuela and Argentina, Lexington, Massachusetts, Lexington Books, D. C. Heath and Company.

Nabe, O. (1983): Military expenditure and industrialization in Africa, Journal of Economic Issues, vol. 17, No. 2, June.

Ospina Sardi, J. (1991): Bases para el Plan Estratégico de Desarrollo de las Fuerzas Armadas 1991 - 1995, Santafé de Bogotá, Departamento Nacional de Planeación.

Paret, P. (1986): Makers of Modern Strategy: from Machiavelli to the Nuclear Age, Princeton, New Jersey, Princeton University Press. 
Pivetti, M. (1990): Military spending as a burden on growth: An underconsumptionist critique, Cambridge Journal of Economics, vol. 16, No. 4, Cambridge, U.K., Academic Press Limited.

Ponton Laverde, G. (1968): Apuntes sobre economía de guerra, Revista de las Fuerzas Armadas, vol. 18, No. 52, Santafé de Bogotá, Imprenta y Publicaciones de las Fuerzas Militares.

Porter, R. (1989): Recent trends in LDC military expenditures, World Development, vol. 17, No. 10, Oxford, U.K., Pergamon Press, October.

Rasier, K. and W. Thompson (1988): Defense burdens, capital formation, and economic growth: The systemic leader case, Journal of Conflict Resolution, vol. 32, No. 1, Sage Publications, Inc., March.

Restrepo Salazar, J. C. and L.I. Betancur Escobar (1995): Aspectos económicos del conflicto colombo-peruano 1932 - 1934, Santafé de Bogotá, Ministry of National Defence.

Ruiz Nova, A. (1997): Defensa, seguridad ciudadana y gasto público, Revista de las Fuerzas Armadas, vol. 52, No. 162, Santafé de Bogotá, Imprenta y Publicaciones de las Fuerzas Militares.

Sandler, T. and K. Hartley (1995): The Economics of Defence, London, Cambridge University Press.

Scheetz, T. (1990): El costo laboral de la seguridad externa e interna: los casos de la Argentina, Chile, Paraguay y Perú, 1969-1988, Desarrollo económico, vol. 30, No. 118, Buenos Aires, Instituto de Desarrollo Económico y Social (IDES).

(1991): The macroeconomic impact of defence expenditures: Some econometric evidence for Argentina, Chile, Paraguay and Peru, Defence Economics, vol. 3, London, Duckworth.

(1993): El marco teórico, político y económico para una reforma militar en la Argentina, Serie de docu- mentos de trabajo, No. 50, Buenos Aires, Centro de Investigaciones Europeo-Latinoamericanas (EURAL).

Schelling, T. C. (1980): The Strategy of Conflict, Cambridge, Massachusetts, Harvard University Press.

Smith, R. (1977): Military expenditure and capitalism, Cambridge Journal of Economics, vol. 1, No. 1, Cambridge, U.K., Academic Press Limited, March.

Smith, D. and R. Smith (1986): La economía del militarismo, Madrid, Editorial Revolución S.A.L.

Soto, A. (1991): La seguridad y la defensa en América Latina en los años noventa: retos y perspectivas, Documentos ocasionales, No. 24, Santafé de Bogotá, University of the Andes, Centro de Estudios Internacionales, November-December.

Thee, M. (1986): Carrera armamentista y tecnología y estrategia militares, Comercio Exterior, vol. 36, No. 12, Mexico City, December.

Thompson, E. (1974): Taxation and national defense, Journal of Political Economy, vol. 82, Chicago, Illinois, The University of Chicago Press, July-August.

United Nations Regional Centre for Peace, Disarmament and Development in Latin America and the Caribbean (1994): Proliferación de armamentos y medidas de fomento de la confianza y la seguridad en América Latina, Lima.

United States, U.S. Arms Control and Disarmament Agency (1996): World Military Expenditures and Arms Transfers, Washington, D.C.

Viñas, A. (1985): Principales interacciones del gasto militar y el subdesarrollo. Un resumen de la literatura reciente, Comercio Exterior, vol. 35, No. 3, Mexico City, March.

Wulf, H. (1980): Transnational Arms Production Technology, Hamburg, University of Hamburg, Institut für Friedensforschung und Sicherheitspolitik. 